\title{
Literary Meaning of Anxiety reflected by the Servant found in 'Appointment in Samarra' by Somerset Maugham
}

\author{
Siti Fatimah \\ SMP Negeri 44 Surabaya, e-mail: fatimah250276@gmail.com \\ Septi Koestiani \\ SMP Negeri 49 Surabaya, e-mail: septikoestiani@gmail.com
}

\begin{abstract}
This research was conducted to describe the semantics analysis of the literary meaning of anxiety in the story 'Appointment in Samara' written by Somerset Maugham. This research applied descriptive qualitative method. The instrument was the researcher himself, and supporting by the secondary instrument called the scripted text of the story examined. The data collection were taken from internet, it was the text of the story 'Appointment in Samara'. To analyze all data, this study used the theory of literary meaning proposed by Lyons (1977). The data were indentified, then were classified, were displayed, and were described. The results of the study showed there were three kinds defense mechanism of reactions in anxiety namely: (1) regression, (2) repression, and (3) rationalization.
\end{abstract}

Keywords: semantics analysis, literary meaning, anxiety

\section{INTRODUCTION}

In linguistics, the study that relates to meaning is called semantics. Semantics is one of linguistics branches, which studies about language meaning, or it can be said that meaning as the main study in semantics term. According to what has long been the most widely accepted theory of semantics, meanings are ideas or concepts, that can be transferred from the mind of the speaker to the mind of the hearer by embodying them, as it were, in the form of one language or another (Lyons, 1977, p. 136).

Interpreting literary work involves more than simply translating text (Hodges, 2011), it is an act of transferring the meaning across cultures. An interpretation result can be considered successful if the overall messages, thoughts, ideas, and concepts in the source language can be delivered into the target language. It is same with translating imagery language, translator must transfer overall messages and ideas, and hence the 
translator must keep the aesthetic aspects. To make the translation acceptable for the target reader, the translators should consider their target reader and make some adjustment. It means that a translator must have a good knowledge of both the language to make translated text does not seem to be translated. Readers have to think that they are reading the original text, thus the translators have to make themselves invisible.

Literal and non-literal meaning is a part of semantic studies. Literal meaning is the opposite of non-literal meaning. Literal meaning is when the speaker says something that has natural meaning or does not have other meaning. While, non-literal meaning is when the speaker says something that has different meaning of what his/her words or has hidden meaning. The two meanings are described in the semantics field which is known as the literary meanings in every literary work such as novel, comic, poem, poetry and so forth (Lyons, 1977).

Literary meaning is the use of words that go beyond their ordinary meaning. It requires the readers to use his/ her imagination to figure out the author's meaning. It makes imagery meaning is difficult to understand because people cannot find the meaning of the imagery language in dictionary just like the other vocabulary words that we usually use in our daily conversation (Chomsky, 2002). To know the meaning of language applied, people need to use our imagination to imagine what the words are said or what the words refer to.

To interpret this short story, the writer used psychological technique. It is because the writer wants to know more about defense mechanism that is anxiety which is used to express the servant feeling in the short story. There are some kinds of anxiety which probably find in this fiction that is: Repression, Regression, and Rationalization. Further in this paper, the writer will try to analyze in which part of these kinds of anxiety are reflected to the short story by Somerset Maugham.

This study was done to describe the semantics analysis on the anxiety case faced by the servant in the story. This study entitled "Semantics Analysis of Literary Meaning of Anxiety reflected by the Servant found in 'Appointment to Samarra' by Somerset Maugham". This title was chose due to it was analyzed about how to interpret this fiction within one of the characters in the story. In addition, it analyzed about defense mechanism 
that is anxiety in as experience of the merchant and the servant in the fiction by Somerset Maugham.

Focusing on the background mentioned, it was formulated the problems of the study as follow: first, the fiction by Somerset Maugham is suitable to analyze with psychological technique. It is because the story tells about someone who tried to avoid his fate. He became frustration and he try to defense him by running away to Samara; and second, the servant tries to defense himself by anxiety. Anxiety is the part of defense mechanism, but it is still as a whole. Anxiety can be divided into some parts such as repression, rationalization, etc. Here, the writer tries to analyze which anxiety that used by the servant to defense himself.

Fiction is a work of the imagination or invention, which contrasts with non-fiction (which is usually thought to be based on facts). Written works like novels, short stories, plays, and poem are fictional. A work of fiction is a work of literature, but the term "literature" encompasses far more than just fiction. Literature also refers to non-fiction (memoirs, biography, and other works that are factual in scope).

Fiction is a general term used to describe an imaginative work of prose, either a novel, short story, or novella. Recently, this definition has been modified to include both nonfiction works that contain imaginative elements, like Midnight in the Garden Of Good and Evil by John Berendt (Random House, 1994) and Dutch by Edmund Morris (Random House, 1999), and novels consisting largely of factual reporting with a patina of fictionalization, such as Memoirs of a Geisha by Arthur Golden (Knopf, 1997). However, in the truest sense, a work of fiction is a creation of the writer's imagination.

The two main types of fiction are literary and commercial. Commercial fiction attracts a broad audience and may also fall into any subgenre, like mystery, romance, legal thriller, western, science fiction, and so on. For example, The Bridges of Madison County by Robert James Waller (Warner, 1992) was a hugely successful commercial novel because the book described the fulfillment of a romantic fantasy that is dear to the heart of millions of readers. Written in a short, easy-to-read style, the book was as mesmerizing to 15 -year-olds as it was to 100 -year-olds. Other blockbuster commercial 
fiction authors include John Grisham, Sidney Sheldon, Danielle Steele, and Jackie Collins.

Literary fiction tends to appeal to a smaller, more intellectually adventurous audience. A work of literary fiction can fall into any of the subgenres described in the following sections. What sets literary fiction apart, however, is the notable qualities it contains excellent writing, originality of thought, and style that raise it above the level of ordinary written works. A recent work of literary fiction that enjoyed wide popularity was Cold Mountain by Charles Frazier (Atlantic Monthly Press, 1997). Other popular authors of literary fiction include Toni Morrision, Barbara Kingsolver, John LeCarre, and Saul Bellow.

A defense mechanism is a strategy used to cover up or change unconscious desires and wishes that may be inappropriate or difficult to express. A defense mechanism is a way for the mind to protect us from being consciously aware of thoughts or feelings that are too difficult to tolerate. Since the thought or feeling is too difficult to tolerate the defense mechanism only allows the unconscious thought or feeling to be expressed indirectly in some type of disguised form. Doing this allows us to reduce anxiety that is caused by the unconscious thought or feeling.

Defense mechanisms are psychological mechanisms aimed at reducing anxiety. They were first discussed by Sigmund Freud as part of his psychoanalytic theory and further developed by his daughter, Anna Freud. Alfred Adler and others also identified additional mechanisms. Often unconscious, defense mechanisms are used to protect an individual from psychological pain or anxiety.

While such mechanisms may be helpful in the short term, alleviating suffering that might otherwise incapacitate the individual, they can easily become a substitute for addressing the underlying cause and so lead to additional problems. The solution, therefore, is to address the underlying causes of the pain these mechanisms are used to defray. The ideal, however, would be for individuals to grow and live in a healthy psychological environment, in a society that cares for and nurtures each person, so that the use of these defense mechanisms is not necessary. 
Sigmund Freud was the first person to develop the concept of defense mechanism; however it was his daughter, Anna Freud, who clarified and conceptualized them. She described ten different defense mechanisms: denial, displacement, intellectualization, projection, rationalization, reaction formation, regression, repression, sublimation, and suppression. Later researchers have added some more defense mechanisms to the list: compensation (first described by Alfred Adler), dissociation, fantasy, identification, undoing, and withdrawal. There is no theoretical consensus on the number of defense mechanisms. Classifying defense mechanisms according to some of their properties (i.e. underlying mechanisms, similarities or connections with personality) has been attempted.

Anxiety is an unpleasant state of inner turmoil, often accompanied by nervous behavior, such as pacing back and forth, somatic complaints and rumination. It is the subjectively unpleasant feelings of dread over something unlikely to happen, such as the feeling of imminent death. Anxiety is feeling unrealistic fear, worry, and uneasiness, usually generalized and unfocused. It is often accompanied by restlessness, fatigue, problems in concentration, and muscular tension. Anxiety is not the same as fear, which is felt about something realistically intimidating. Anxiety is not considered to be a normal reaction to a perceived stressor although many feel it occasionally. When anxiety becomes overwhelming and distressing to the sufferer, it may fall under the psychiatric diagnosis of anxiety disorder. Anxiety is not the same as fear. Fear is evoked by a realistic danger and is an appropriate response to a perceived threat, while anxiety is worry or overreaction to a situation that is only subjectively seen as menacing.

According to Freud, anxiety is an unpleasant inner state that people seek to avoid. Anxiety acts as a signal to the ego that things are not going right. There are three kinds defense mechanism of reactions in anxiety:

1. Regression

Regression is a movement back in psychological time when one is faced with stress. When we are troubled or frightened, our behaviors often become more childish or primitive. A child may begin to suck their thumb again or wet the bed when they need to spend some time in the hospital. Teenagers may giggle uncontrollably when introduced into a social situation involving the opposite sex. 


\section{Repression}

Repression is the unconscious blocking of unacceptable thoughts, feelings and impulses. The key to repression is that people do it unconsciously, so they often have very little control over it. "Repressed memories" are memories that have been unconsciously blocked from access or view. But because memory is very malleable and ever-changing, it is not like playing back a DVD of your life. The DVD has been filtered and even altered by your life experiences, even by what you've read or viewed.

3. Rationalization

In psychology, rationalization is the process of constructing a logical justification for a decision that was originally arrived at through a different mental process. This process can range from fully conscious (e.g. to present an external defense against ridicule from others) to mostly subconscious (e.g. to create a block against internal feelings of guilt). Simply put, rationalization is making excuses for one's mistakes, and by doing so avoiding self-condemnation or condemnation by others.

There are two types of rationalization. One is "sour grapes," a term from Aesop's fable about the fox who said that the grapes too high to reach were sour anyway. For example, a person after failing to get into a law school may justify himself by saying: "I would have hated being a lawyer anyway." The second, more productive type of the rationalization is the "silver lining," an assumption that everything happens for the best, so one should try to find the blessing in disguise. "So, I didn't get into law school, but now I can really focus on finding my true vocation."

Rationalization is a post-hoc (after the fact) defense mechanism, connected to the self-serving bias: failure is ascribed to outside factors, whereas success comes from oneself. Rationalization is when something happens that we find difficult to accept, then we will make up a logical reason why it has happened. The target of rationalization is usually something that we have done, such as being unkind to another person. It may also be used when something happens independent of us which 
causes us discomfort, such as when a friend is unkind to us. We not only rationalize actions and the things we have done, we also find reason for our beliefs, models, values and other inner structures and thoughts. These systems are often implied in rationalization statements. We rationalize to ourselves. We also find it very important to rationalize to other people, even those we do not know.

The method applied in this study was descriptive qualitative method for implementation this study because this study was intended to describe the literary meaning of language used in the story focusing on the anxiety of the servant by using the form of description. Qualitative method is applied as research procedures that result descriptive data containing spoken and written words from the people and behaviors of people which can be observed in the research (Moleong, 2010, p. 4). In this study, descriptive method was chosen because all of the data examined in this study were described, classified and analyzed descriptively. Moreover, qualitative approach was used to analyze the data containing the literary meaning of anxiety in the languages used in the selected story by Somerset Maugham entitle 'Appointment in Samara'.

The primary instrument of this study was the researcher himself because this study was appropriate to descriptive qualitative research. One of the characteristics of qualitative research is that the research mainly uses human being or the researcher himself/herself as the main instrument of the research conducted (Moleong, 2010, p. 121). Moreover, the researcher becomes the designer, data collector, analyst, interpreter, and also result reporter of the research in the research conducted.

All of data in this research were qualitative data. As descriptive qualitative research, data collection techniques included observations of targeted events and the examination of documents. Data collection methods are the way of collecting data used in this research. There were some data collection methods or steps applied in order to obtain data used in this study. In this study the researcher used qualitative approach in which the data were in the form of words, phrases, and sentences used in the selected story by Somerset Maugham.

Some steps of collecting the data in this study were taken in order to find types of anxiety defenses as the literary meaning of language applied in the story and gained the 
meanings interpreted in the data examined. First, collecting the text of the story by browsing in the internet. Second, reading and understanding the text of the selected story. Third, identifying out all the words, phrases and sentences containing the literary meaning of anxiety languages found in the data of this study. Then, classifying the data based on the types of literary meaning of anxiety languages used in the data analyzed and describing them into their literary meaning of anxiety languages. Lastly, drawing the conclusion based on the data findings.

The researcher described the primary steps in order to analyze the data of this study involving identification, classification, interpretation, and drawing the conclusion. First, in identification step, the researcher was to identify the figurative languages used in the selected story by Somerset Maugham by recognizing the characteristics of literary meaning of anxiety languages supported by theories from Lyons (1977). All of literary meaning of anxiety languages identified by researcher being written on observation field note.

Furthermore, the second step was classification the data based on the types of literary meaning of anxiety languages used. Then, interpretation the data by describing the literary meaning of anxiety languages used in the selected story as the data examined which was supported by some related theories applied. After that, researcher was to explain the interpretation with the rich description. Lastly, the researcher drew the conclusion based on the data findings in this study conducted.

\section{DISCUSSION}

Answering the two formulated problems on the background of this study, the researcher presented the findings into the description forms as the design of this study. There was a merchant in Bagdad who sent his servant to market to buy provisions, and in a little while the servant came back, white and trembling, and said," Master, just now when I was in the marketplace I was jostled by a woman in the crowd and when I turned I saw it was Death that jostled me. She looked at me and made a threatening gesture"; "Now, lend me your horse, and I will ride away from this city and avoid my fate. I will go to Samarra and there Death will not find me." The merchant lent him his horse, and 
the servant mounted it, and he dug his spurs in its flanks and as fast as the horse could gallop he went. Then the merchant went down to the marketplace and he saw me standing in the crowd and he came to me and said, "Why did you make a threatening gesture to my servant when you saw him this morning?" "That was not a threatening gesture", I said, "It was only a start of surprise. I was astonished to see him in Bagdad, for I had an appointment with him tonight in Samarra."

Based on three kinds of anxiety, we can show examples of the three kinds of anxiety in this short story. Those are:

1. Regression

Regression is the anxiety that means when somebody in trouble or afraid they are usually become childish. This regression can be found in the expression below: "Now, lend me your horse, and I will ride away from this city and avoid my fate."

This expression above means that the servant tried to avoid his fate. He became childish because he know that death can't be avoid when the time coming.

2. Repression

Repression means the expression when someone try to forget the unwanted thoughts, feelings, and impulses. This repression can be found in the expression below:

\section{"I will go to Samarra and there Death will not find me."}

This expression above means that the servant tried to forget reality of his death. He thought with go to Samarra he can still alive.

3. Rationalization

Rationalization means that when someone in panic, fear, and worry they usually set their self-esteem by making logical reason. Rationalization can be found in the expression below:

"Master, just now when I was in the marketplace I was jostled by a woman in the crowd and when I turned I saw it was Death that jostled me. She looked at me and made a threatening gesture." 
In this expression the servant rationalized his mind by making statement that the death made a threatening gesture to him. He used it as the reason for lent his merchant horse. In the end of the story death clarified with the expression below.

"That was not a threatening gesture", I said, "It was only a start of surprise. I was astonished to see him in Bagdad, for I had an appointment with him tonight in Samarra."

This expression proved that the servant misunderstood with the death gesture. "That was not a threatening gesture. It was only a start of surprise," death said.

\section{CONCLUSION}

The fiction "The Appointment in Samarra" by Somerset Maugham tells about the reality of death. Death is personified as a person who is very professional, which keeping an appointment with people that she will kill. She tries to meet the servant (a person who she will kill) in Bagdad, but when she saw him, the servant think that she making threatening gesture. The servant afraid and try to avoid her by lent his merchant's house to go to Samarra (a place which he think that death will not find him). Finally, the death was making appointment to him in Samarra because actually fate can't be avoided. In this fiction, the writer can find three kinds of anxiety that are regression, repression, and rationalization. Those are can be proved in some expression delivered by the character.

\section{REFERENCES}

Chomsky, N. (2002). Syntactic Structures. Berlin : Mouton de Gruyter.

Lyons, J. (1977). Semantics. Cambridge: Cambridge University Press.

Moleong, J. (2010). Metodologi Penelitian Kualitatif. Bandung: PT Remaja Rosdakarya.

Online references are available on:

http://www.newworldencyclopedia.org/entry/Defense_mechanism

http://www.k-state.edu/english/baker/english320/Maugham-AS.htm 